Prince, A. M., Szmuness, W., Millian, S. J., and David, D. S. (1971). A serologic study of cytomegalovirus infections associated with blood transfusions. New England fournal of Medicine, 284, 1125.

Weller, T. H., and Hansaw, J. B. (1962). Virologic and clinical observations on cytomegalic inclusion disease. New England Fournal of Medicine, 266, 1233.

M. Umetsu, Y. Chiba, K. Horino, S. Chiba, and T. NAKAO

Department of Paediatrics, Sapporo Teishin Hospital and Sapporo Medical College, Sapporo, Japan.

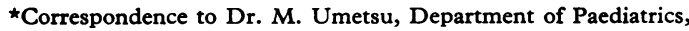
Sapporo Teishin Hospital, Sapporo, 060, Japan.

\section{Rupture of the spleen in erythroblastosis fetalis}

Rupture of the spleen in the newborn is a rare occurrence. Giedion (1963), reviewing this problem, could find only 25 published cases, and subsequently Leape and Bordy (1971) collected reports on only 18 neonates successfully treated for rupture of the spleen. Breech presentation or difficult vertex delivery has been held responsible for this injury in some cases, but more often no specific type or complication of delivery can be incriminated. Though there are more reports of rupture of normal spleen, it is well known that a pathologically enlarged spleen, usually due to erythroblastosis or in the past to syphilis (Lundquist, 1930), can rupture. Sirola (1967) has reported the only successfully treated newborn infant who had erythroblastosis, splenic rupture, and successful management includ- ing splenectomy. The following case is reported as representing a further example of an infant with similar pathology who has survived.

\section{Case report}

A male infant was born by spontaneous vertex delivery at 36 weeks' gestation after induction of labour because of severe rhesus isoimmunization. The mother, a gravida 2 para 1 and abortus 1 , was group 0 rhesus negative $\bar{c}$ de/ $/ \bar{c}$ de. There had been a marked rise in antibody titre to anti C+D from 29 to 36 weeks' gestation, the titre in saline and indirect antiglobulin test reaching $1 / 512$. The optical density difference of the amniotic fluid had risen from lower zone II of Liley's curve at 31 weeks to upper zone II at 34 weeks.

The infant weighed $3080 \mathrm{~g}$ and his general condition was satisfactory with an Apgar score of 4 at 1 minute and 9 at 5 minutes. The liver was not enlarged and the spleen was just palpable. A left hydrocele was noted. The cord blood was group 0 rhesus positive, direct antiglobulin test positive, antibody titre by indirect antiglobulin test $1 / 128$ for anti $C+D$, and serum bilirubin $6.8 \mathrm{mg} / 100 \mathrm{ml}$. Capillary haemoglobin was $12.0 \mathrm{~g} / \mathrm{dl}$, packed cell volume $0 \cdot 37$, and platelet count 192000 / $\mathrm{mm}^{3}$ with normal RBC morphology and thrombotest $100 \%$.

At $2 \frac{1}{2}$ hours the infant's condition deteriorated with the development of circulatory failure. Immediate exchange transfusion was followed by improvement in the infant's condition. The haematological data are given (see Table). Phenobarbitone and phototherapy were started. At 14 hours petechiae on the trunk were noted, the abdomen was slightly distended, and the left hydrocele felt more firm. Hypoglycaemia was treated and a second exchange transfusion was carried out at 24 hours to correct the anaemia and remove antibodies. By 48 hours the haemoglobin had fallen again to

\title{
TABLE
}

Haematological and biochemical data

\begin{tabular}{|c|c|c|c|c|c|c|c|c|}
\hline & Age (h) & $\begin{array}{c}\text { Fragmen- } \\
\text { tation } \\
\text { of } \\
\text { RBC }\end{array}$ & $\underset{(\mathbf{g} / \mathrm{dl})}{\mathbf{H b}}$ & $\begin{array}{l}\text { Platelets } \\
\left.\text { (per } \mathrm{mm}^{3}\right)\end{array}$ & $\begin{array}{l}\text { Coagulation } \\
\text { factors }\end{array}$ & $\underset{(\mathbf{m g} / \mathrm{ml})}{\mathbf{F D P}}$ & 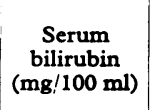 & $\begin{array}{c}\text { True blood } \\
\text { glucose } \\
(\mathrm{mg} / 100 \mathrm{ml})\end{array}$ \\
\hline Cord Blood & Birth & 0 & $\begin{array}{c}12 \cdot 0 \\
\text { (capillary } \\
\text { sample) }\end{array}$ & 192000 & - & 一 & $6 \cdot 8$ & - \\
\hline \multirow{2}{*}{$\begin{array}{cc}\text { 1st exchange } & \text { trans- } \\
\text { fusion } & \text { Pre } \\
& \text { Post }\end{array}$} & & & & & & & & \\
\hline & $\begin{array}{r}3 \\
14 \\
18\end{array}$ & $\frac{+}{0}+$ & $\begin{array}{r}9 \cdot 7 \\
14 \cdot 3 \\
\frac{9 \cdot 5}{9 \cdot 5}\end{array}$ & $\begin{array}{c}100000 \\
75000 \\
57000\end{array}$ & $\begin{array}{l}\text { I, V, VIII } \downarrow \\
\text { VIII } \downarrow \\
=\end{array}$ & $\begin{array}{c}>40<80 \\
>40<80 \\
=\end{array}$ & $\begin{array}{l}6.9 \\
5.0 \\
\frac{-}{6.9}\end{array}$ & $\begin{array}{r}292 \\
156 \\
2 \\
-\end{array}$ \\
\hline \multicolumn{9}{|l|}{$\begin{array}{l}\text { 2nd exchange trans- } \\
\text { fusion }\end{array}$} \\
\hline $\begin{array}{r}\text { Pre } \\
\text { Post }\end{array}$ & $\begin{array}{l}24 \\
40 \\
48\end{array}$ & $\begin{array}{l}+ \\
0 \\
0 \\
\pm\end{array}$ & $\begin{array}{r}6 \cdot 5 \\
13 \cdot 6 \\
8 \cdot 1 \\
7 \cdot 2\end{array}$ & $\begin{array}{l}45000 \\
49000 \\
58000 \\
90000\end{array}$ & $\begin{array}{c}\text { I } \pm \text { VII } \downarrow \\
\overline{\text { Normal }} \\
I, \text { VIII } \pm \text { VII } \downarrow\end{array}$ & $\begin{array}{c}>160<320 \\
>40<80 \\
=\end{array}$ & $\begin{array}{l}5 \cdot 8 \\
4 \cdot 7 \\
6 \cdot 7 \\
-\end{array}$ & $\begin{array}{r}270 \\
62 \\
=\end{array}$ \\
\hline
\end{tabular}

RBC, red blood cells; FDP, fibrin degradation products. 


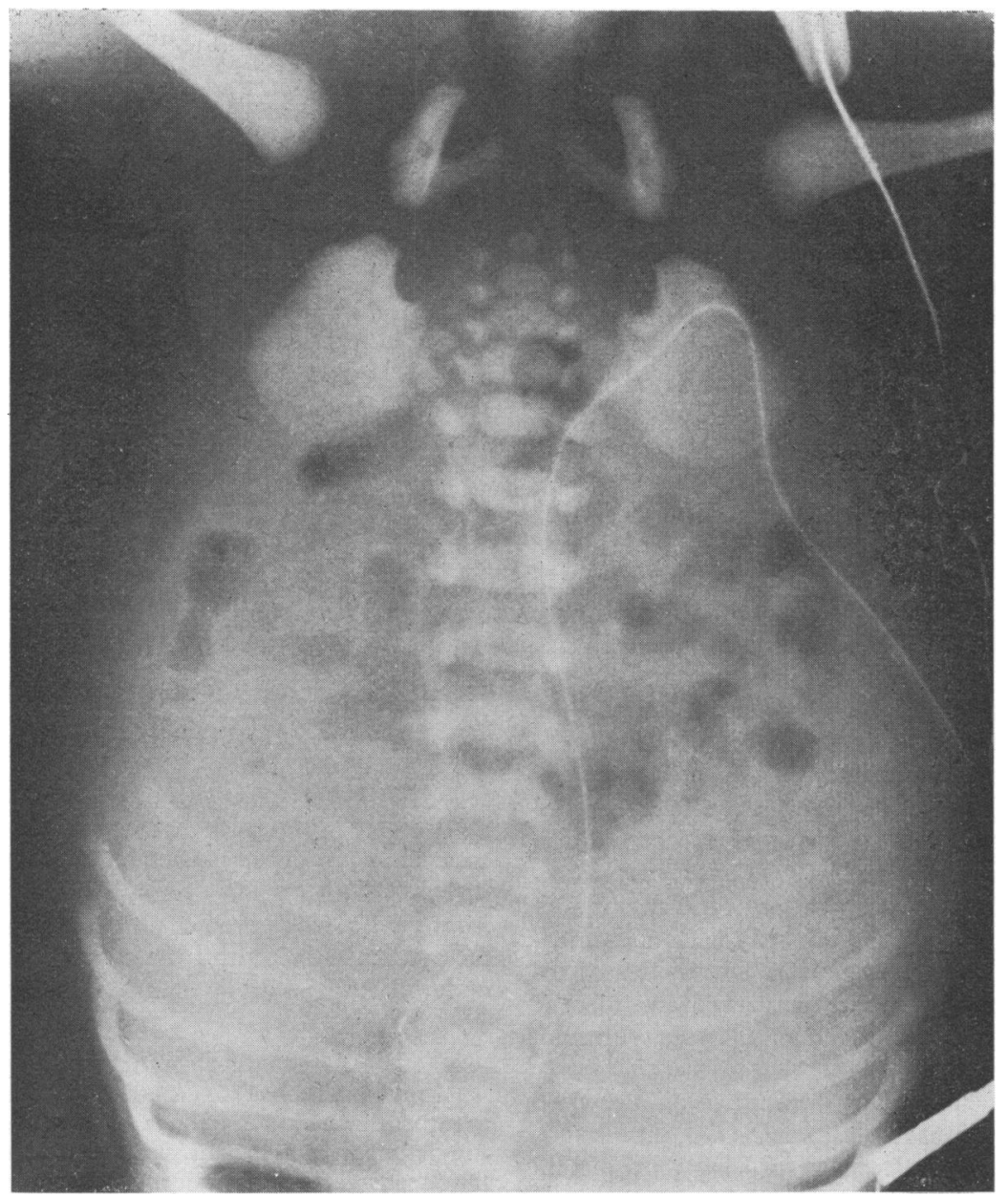

FIG.-Opacity in left hypochondrium, displacement of stomach to the right with angulation of the nasogastric tube.

$7 \cdot 2 \mathrm{~g} / \mathrm{dl}$, but the bilirubin remained low at $6.7 \mathrm{mg} /$ $100 \mathrm{ml}$. The presence of haemoperitoneum was confirmed by an abdominal paracentesis in the left lower quadrant. $X$-ray of the abdomen (see Fig.) showed displacement of the stomach and the bleeding was presumed to come from a ruptured spleen. A transfusion of $50 \mathrm{ml}$ partially packed cells was given and the baby transferred to the Royal Hospital for Sick Children. Laparotomy revealed a large volume of blood in the peritoneal cavity originating from the spleen, the capsule of which was torn in the region of the spleno-lieno-renal ligament. Also there was a large left suprarenal haemorrhage displacing the kidney and a smaller right suprarenal haemorrhage. Splenectomy was performed and postoperative progress was satisfactory. Plasma cortisol levels were normal, as was the response to Synacthen. The spleen weighed $14 \mathrm{~g}$. Histologically it showed distended sinusoids which contained erythro- blasts and focal subcapsular haemorrhage with at one point rupture through the capsule. At 3 weeks of age a pyelogram showed that the left kidney was still displaced, presumably secondary to the adrenal haemorrhage. The infant has progressed normally since discharge from hospital. In view of the increased susceptibility of the splenectomized infant to severe infections (Diamond, 1969), prophylactic penicillin has been continued.

\section{Discussion}

Early recognition of this uncommon complication of erythroblastosis with institution of appropriate treatment is essential to a successful outcome. In the Royal Maternity Hospital, Glasgow, there have been only two other cases of ruptured spleen in the last 23 years, both had erythroblastosis and both 
died, and at the Royal Hospital for Sick Children no case of perinatal splenic rupture has been admitted in the last 14 years.

Diagnosis is not easy in the infant who has had exchange transfusion as some abdominal distension is common after such a procedure. The diagnosis of haemoperitoneum in this patient was confirmed by paracentesis. Abdominal tap is of value when positive, but if negative is not always reliable. In this case the unusual feature was the low serum bilirubin even considering the effect of phototherapy. Presumably the large amount of the infant's blood which was in the peritoneal cavity was unavailable for breakdown and conversion to bilirubin.

The thrombocytopenia, fragmentation of RBC, consumption of factors, particularly I, V, VIII, and later probably VII, together with the release of fibrin degradation products (FDPs) was most likely due to the local stimulation of coagulation from thromboplastins released from the ruptured spleen. Though causing a further fall in platelets, the exchange transfusion with ACD blood seemed to halt the consumption of factors and to lower the level of FDPs. There may also have been an element of disseminated intravascular coagulation (Chessells and Wigglesworth, 1971) but hypotension and local coagulation were probably the major factors in this case. The coagulopathy with consumption of platelets and coagulation factors was probably responsible for the continuation of the haemorrhage, initiating a vicious circle (Digilio, Bacchetta, and Ferreri, 1960).

In the present case it was difficult to define when the suprarenal haemorrhages occurred. The hypotension and coagulopathy were probably important contributory factors.

\section{Summary}

A male infant of 36 weeks' gestation, weighing $3080 \mathrm{~g}$, with erythroblastosis, ruptured spleen, and bilateral suprarenal haemorrhages is described. The infant survived after exchange transfusions and splenectomy.

We are grateful to Drs. J. M. Scott and J. C. Maclaurin, and Mr. D. G. Young for helpful criticism.

\section{REFERENCES}

Chessells, J. M., and Wigglesworth, J. S. (1971). Haemostatic failure in babies with rhesus isoimmunization. Archives of Disease in Childhood, 46, 38.

Diamond, L. K. (1969). Splenectomy in childhood and the hazard of overwhelming infection. Pediatrics, 43, 886.

Digilio, G., Bacchetta, V., and Ferreri, A. (1960). Un caso di rottura spontanea della milza in un neonato con grave deficit emocoagulativo. Haematologica, 45, 1005.

Giedion, A. (1963). Die geburtstraumatische Ruptur parenchymatöser Bauchorgane Leber, Milz, Nebenniere und Niere) mit massivem Blutverlust und ihre radiologische Darstellung. Helvetica Paediatrica Acta, 18, 349.

Leape, L. L., and Bordy, M. D. (1971). Neonatal rupture of the spleen. Report of a case successfully treated after spontaneous cessation of hemorrhage. Pediatrics, 47, 101.

Lundquist, B. (1930). Hémorragies intra-thoraciques et intraabdominales chez le nouveau-né. Acta Obstetrica et Gynecologica Scandinavica, 8, 331 .

Sirola, K. (1967). Subcapsular bleeding of the spleen with rupture in a newborn infant with erythroblastosis fetalis. Fournal of Pediatric Surgery, 2, 155.

J. B. S. CoulteR ${ }^{\star}$ and P. A. M. RAINE

Department of Neonatal Paediatrics, Royal Maternity Hospital, and Department of Paediatric Surgery, Royal Hospital for Sick Children, Glasgow.

*Correspondence to Dr. J. B. S. Coulter, Department of Paediatrics, Ahmadu Bello University, Zaria, Nigeria.

\section{Hypertension, oedema, and suppressed renin aldosterone system due to unsupervised salt administration}

Hypernatraemia is recognized as a complication of incorrectly prepared hyperosmolar infant feeds, especially in the presence of acute diarrhoeal disease (Taitz and Byers, 1972). We report an infant who was given a glucose-salt-water mixture on medical advice and developed hypertension and oedema after being given an excess of salt.

\section{Case report}

A previously healthy, bottle-fed Asian girl, aged 3 months, developed diarrhoea. After 3 days the parents sought medical help and were advised to give her clear fluid feeds prepared by adding 5 teaspoons of glucose and 1 saltspoon of salt to $600 \mathrm{ml}(20 \mathrm{fl} \mathrm{oz})$ water. Having no saltspoon in the house, they prepared each feed by adding 2 teaspoons of glucose and 5 pinches of salt to $240 \mathrm{ml}$ $(8 \mathrm{fl} \mathrm{oz}$ ) water. The baby drank eagerly one litre of the glucose saline solution every 24 hours. Urine output appeared normal and she had 5 loose stools a day. During the next 3 days she developed swelling of the face, abdomen, and legs, and was admitted to The Hospital for Sick Children.

She had gained $450 \mathrm{~g}$ in weight, had facial and leg oedema, and her blood pressure was $140 / 80 \mathrm{mmHg}$. Investigations showed plasma sodium $144 \mathrm{mEq} / \mathrm{l}$, potassium $3.6 \mathrm{mEg} / \mathrm{l}$, urea $5 \mathrm{mg} / 100 \mathrm{ml}$, urine osmolality $66 \mathrm{mOsm} / 1$, and 24-hour urine sodium $20 \mathrm{mEq}$. Plasma creatinine and albumin were normal. Plasma renin activity (PRA) was subnormal on admission (55 $\mathrm{pgAI} / \mathrm{ml} \mathrm{per} \mathrm{h)} \mathrm{and} \mathrm{was} \mathrm{associated} \mathrm{with} \mathrm{a} \mathrm{low} \mathrm{plasma}$ aldosterone concentration (PAldo) of $11.9 \mathrm{ng} / 100 \mathrm{ml}$. Mean values for children of this age are 1392 (range 4723130) $\mathrm{pgAI} / \mathrm{ml}$ per $\mathrm{h}$ and $20 \cdot 2$ (range $8 \cdot 3-75$ ) $\mathrm{ng} /$ $100 \mathrm{ml}$, respectively (Dillon and Ryness, 1974). 